\title{
Prohibit WP2 - systematic review of national guidelines in European countries
}

\author{
M Martin ${ }^{1 *}$, C Wilson ${ }^{1}$, W Zingg ${ }^{2}$, S Hansen ${ }^{3}$, P Gastmeier ${ }^{3}$, D Pittet ${ }^{2}$, M Dettenkofer ${ }^{1}$, PROHIBIT consortium \\ From International Conference on Prevention \& Infection Control (ICPIC 2011) \\ Geneva, Switzerland. 29 June - 2 July 2011
}

\section{Introduction / objectives}

The European Commission (FP-7) funded project PROHIBIT (Prevention of Hospital Infections by Intervention and Training) was established in 2010. WP2 of PROHIBIT aims to analyse existing national guidelines, practices in surveillance and public reporting of healthcare associated infections (HAI) in Europe.

\section{Methods}

The ECDC-HAI surveillance National Contact Points (NCP) and experts in 34 countries (27 EU member states, whereby UK counts as 4 countries, Croatia, Iceland, Norway and Switzerland) were invited to complete a questionnaire and give information about existing national guidelines for prevention of surgical site infection (SSI), ventilator-associated pneumonia (VAP), catheter-associated urinary tract infection (CAUTI), catheter-associated blood stream infection (CA-BSI) and $C$. difficile infection (CDI). The NCPs were requested to state where the guidelines could be found in print or online. Stated websites were searched and compared to answers. In cases of mismatch NCPs were personally contacted for clarification.

\section{Results}

End of March 201132 NCPs (94\%) completed the questionnaire. 14 countries have guidelines on all 5 topics. 7 countries have 4 guidelines, 1 has 3 and 4 have 1.5 countries have no national guidelines. Scientific level of supporting evidence and strength of recommendation are stated in $51 \%$ of the guidelines. In most countries identification of relevant documents was only possible by personal communication with NCPs. Scope, structure and detailing of recommendations vary widely.

${ }^{1}$ University Medical Center Freiburg, Freiburg, Germany

Full list of author information is available at the end of the article

\section{Conclusion}

Evidence-based, national guidelines for prevention of HAI are still to be developed in many European countries. In the majority of countries finding the currently valid guidelines may be difficult for users.

\section{Disclosure of interest}

None declared.

\section{Author details}

${ }^{1}$ University Medical Center Freiburg, Freiburg, Germany. ${ }^{2}$ Hôpitaux

Universitaires de Genève, Genève, Switzerland. ${ }^{3}$ Charité - Universitätsmedizin Berlin, Berlin, Germany.

Published: 29 June 2011

\section{doi:10.1186/1753-6561-5-S6-P318}

Cite this article as: Martin et al:: Prohibit WP2 - systematic review of national guidelines in European countries. BMC Proceedings 2011 5(Suppl 6):P318.
Submit your next manuscript to BioMed Central and take full advantage of:

- Convenient online submission

- Thorough peer review

- No space constraints or color figure charges

- Immediate publication on acceptance

- Inclusion in PubMed, CAS, Scopus and Google Scholar

- Research which is freely available for redistribution

Submit your manuscript at www.biomedcentral.com/submit
C Biomed Central 